\title{
Editorial: Special Issue on the IX Iberic Meeting of Electrochemistry
}

\author{
Enric Brillas ${ }^{a}$, Manuel E. Sastre ${ }^{b}$ \\ ${ }^{a}$ Universitat de Barcelona, e-mail: brillas@ub.edu \\ ${ }^{b}$ Universidadeda Coruña, e-mail: eman@udc.es
}

At present, Electrochemistry is being rapidly developed in different scientific and technological fields that lead to new applications to solve many environmental, energetic and industrial problems. The decontamination of organics and salts from wastewaters and the development of operative fuel cells and new polymeric or nanostructured materials are examples of increasing reasearch over all the world. The rapid diffusion of new information and the contact and discussion between electrochemists in meetings are then essential to ensure the most rapid progress in the knowledgement of all the new trends of Electrochemistry.

This special issue of Portugaliae Electrochimica Acta consists of high quality papers that were presented as plenary lectures or oral communications during the $I X$ Iberic Meeting of Electrochemistry, made in conjunction with the XXVIII Meeting of the Electrochemistry Group of the Spanish Royal Society of Chemistry (RSEQ). It was held in A Coruña (Spain) from 10 to 13 July 2006 and organized by Prof. Dr. M.E. Sastre (U. Coruña). The other members of the Organizing Committee from the Universidade da Coruña were Prof. Drs. J.L. Barriada, I. Brandariz, R. Herrero, F. Peneda, P. Rodríguez and T. Vilariño. The Scientific Committee was composed of Profs. Drs. A. Aldaz (U. Alicante), F. Arce (U. Santiago de Compostela), A. Barros (U. Porto), E. Brillas (U. Barcelona), M. Esteban (U. Barcelona), J. Feliu (U. Alicante), T. Fernández Otero (U. Politécnica de Cartagena), V.M.M. Lobo (U. Coimbra), J.M. López Fonseca (U. Oviedo), J.C. Rodríguez Placeres (U. La Laguna), M. Rueda (U. Sevilla) and J.J. Ruíz (U. Córdoba).

The meeting brought together Spanish and Portuguese electrochemists to present and discuss timely research concerning all fields of Electrochemistry. In addition, two other relevant electrochemist researchers such as Prof. R. Guidelli (U. Firenze, Italy) and Prof. M.A. Oturan (U. Marne La Vallée, France) were also invited to give a plenary lecture. A total of 13 plenary lectures, 3 invited CIDETEC awards and 77 oral communications were presented in three parallel symposia (A, B and C) during a 3-day intensive program divided in the following topics:

A1. Ionic reactions and properties

A2. Charged interfases

A3. Electrochemistry and environment

A4. Bioelectrochemistry

B5. Molecular electrochemistry: mechanistic and analytical aspects

C6. Electrochemistry of materials

C7. Fuel cells

C8. Corrosion 
Of all them, 14 articles including research and review papers that cover most of these topics are published in this issue of Portugaliae Electrochimica Acta.

We are indebted to the Editor Prof. Dr. V.M.M. Lobo and all the reviewers who helped us making this issue an important reference material. Special thanks are expressed to the members of the Organizing and Scientific Committees who made possible the great success of this meeting. Finally, we want also acknowledge the financial support of the Universidade da Coruña, Xunta de Galicia, Ministerio de Educación y Ciencia and $R S E Q$, as well as the enterprises CIDETEC, Trallero \& Schlee, Gomensoro and Galmedic.

Guest Editors 